Note

\title{
Changes in Solubility and Thermal Stability of Chicken Myofibrillar Protein by
}

\section{Glycosylation}

\author{
Kimio Nishimura ${ }^{1 *}$, Miki Murakoshi ${ }^{1}$, Shigeru Katayama ${ }^{2}$ and Hiroki Saeki ${ }^{3}$ \\ ${ }^{I}$ Department of Food Science and Nutrition, Faculty of Human Life and Science, Doshisha Women's College of Liberal Arts, Kamigyo-ku, \\ Kyoto 602-0893, Japan \\ ${ }^{2}$ Department of Bioscience and Biotechnology, Faculty of Agriculture, Shinshu University, 8304 Minamiminowa, Kamiina, Nagano \\ 399-4598, Japan \\ ${ }^{3}$ Graduate School of Fisheries Science, Hokkaido University, Hakodate, Hokkaido 041-8611, Japan
}

Received March 10, 2010; Accepted November 1, 2010

\begin{abstract}
Myofibrillar protein prepared from chicken breast muscle was incubated with several concentrations of glucose or maltose for $6 \mathrm{~h}$ at $60^{\circ} \mathrm{C}$ and $35 \%$ relative humidity in order to obtain glycosylated chicken protein. When the ratio of the weights of the myofibrillar protein and glucose or maltose exceeded 1:6 or 1:3-5, respectively, the solubility of each type of glycosylated chicken protein in $0.1 \mathrm{M} \mathrm{NaCl}$ solution exceeded by about $60 \%$, although the myofibrillar protein was insoluble in a low ionic strength solution. Solubilization of chicken myofibrillar protein required a small quantity of glucose compared with carp myofibrillar protein. Neither sample underwent denaturation when held at $50^{\circ} \mathrm{C}$ for $2 \mathrm{~h}$.
\end{abstract}

Keywords:chicken, myofibrillar protein, glycosylation, Maillard reaction, solubility, thermal stability

Abbreviations: RH, relative humidity; TCA, trichloroacetic acid

\section{Introduction}

Although chicken is cheap and contains nutritious proteins and lipids compared to pork and beef (Youling, 2000), the diversity of its processed food is poorer than that of pork. Therefore, it may be beneficial to develop new functionality of chicken as a material for processed food.

Saeki and colleagues have reported improved functional properties of fish and shellfish myofibrillar proteins by glycosylation using the Maillard reaction (Saeki, 1997; Saeki and Inoue, 1997; Saeki and Tanabe, 1999; Fujiwara et al., 1998; Katayama et al., 2002). Carp and scallop myofibrillar proteins become solubilized in a low ionic strength medium by reaction with glucose and ribose (Saeki and Inoue, 1997; Saeki and Tanabe, 1999; Katayama et al., 2002). Both the emulsifying properties and thermal stability of carp myofibrillar proteins can also be enhanced by conjugation with dextran (Fujiwara et al., 1998). Functional improvement of this protein occurred when lyophilized myofibrillar proteins

*To whom correspondence should be addressed.

E-mail: knishimu@dwc.doshisha.ac.jp were reacted and conjugated with reducing sugars through the early stage of the Millard reaction.

However, the fish muscular protein is thermally less stable than that of other animals (Connell, 1961). Thus, a comparatively large amount of sugar has to be used for glycosylation to prevent denaturation of the fish meat protein (Boye et al., 1996). In fact, Saeki and Inoue used as much as ninefold glucose for the weight of proteins to make myofibrillar proteins of a carp solubilize in low ionic strength medium by glycosylation (Saeki and Inoue, 1997). In contract, muscular proteins of homothermal animals have superior thermal stability (Connell, 1961). Thus, functional alteration in the conjugation of chicken myofibrillar proteins is expected to occur with less sugar than that required for fish.

To expand the availability of neoglycoprotein synthesized using chicken myofibril as a new food material, in this study, we followed the solubility changes of low and high ionic strength media of chicken myofibrillar protein during the reaction with glucose as a monosaccharide or maltose as a disaccharide in relation to the progress of the Maillard reaction. The smallest amount of both sugars showing solubility 
of $60 \%$ or more in low ionic strength medium was examined and this minimum amount was used to investigate thermal stability.

\section{Materials and Methods}

Materials and chemicals Breast meat was removed from chickens immediately after slaughter. The glycosylated human serum calibration kit was purchased from Japan Roche Diagnostic, Inc. (Tokyo, Japan). The other chemicals used were of reagent grade and obtained from Nacalai Tesque, Inc. (Kyoto, Japan), or Wako Pure Chemicals Industries, Ltd. (Osaka, Japan).

Myofibril preparation The chicken myofibril fraction was prepared using a modification of the method of Saeki (1997). Briefly, chicken breast meat was ground with a food chopper and suspended in 10 volumes of $0.1 \mathrm{M}$ sodium phosphate buffer ( $\mathrm{pH}$ 7.5); the supernatant was removed by decantation. This step was repeated twice. The washed and ground meat was homogenized with a homogenizer (AM6; Nissei Co., Ltd., Tokyo, Japan) in 10 volumes (based on initial muscle weight) of $0.1 \mathrm{M}$ sodium phosphate buffer $(\mathrm{pH}$ 7.5 ) for $0.5 \mathrm{~min}$ at $10,000 \mathrm{rpm}$. This step was repeated 3 or more times. After filtration through cotton gauze to remove impurities, $20 \%$ Triton X-100 solution was added to the obtained filtrate to a final concentration of $0.5 \%$ and stirred gently using a stirrer for $3 \mathrm{~min}$. After standing in $10 \mathrm{~min}$, the filtrate was centrifuged at 7,000 $\mathrm{g}$ for $10 \mathrm{~min}$ to collect myofibrils. The precipitate was resuspended in $50 \mathrm{mM} \mathrm{NaCl}$ and centrifuged. This procedure was carried out 3 or more times. The purified chicken myofibril was obtained by filtering through a cotton gauze. All preparation steps were carried out on ice.

Glycosylation of myofibrillar proteins Glycosylation of myofibrillar proteins was performed using a modification of the method of Saeki (1997). Briefly, myofibril suspended in $50 \mathrm{mM} \mathrm{NaCl}$ was mixed with glucose at weight ratios of $1: 4,1: 5,1: 6,1: 9$, and 1:18, and with maltose at weight ratios of $1: 3,1: 4,1: 5$, and $1: 6$. After final protein concentrations were adjusted to $6.0 \mathrm{mg} / \mathrm{mL}, 5 \mathrm{~mL}$ of the myofibril-glucose and myofibril-maltose solution were each placed in a test tube (diameter: $16 \mathrm{~mm}$ ), frozen at $-80^{\circ} \mathrm{C}$, and immediately lyophilized using a freeze-dryer (FD-1; Tokyo Rika Co. Ltd., Tokyo, Japan), destroying the sarcomere and exposing myofibrillar proteins. The lyophilization was stopped when the sample temperature reached $15-18^{\circ} \mathrm{C}$. The lyophilized protein powder was immediately stored at $-40^{\circ} \mathrm{C}$ and used within 30 days of preparation.

To react protein with glucose and maltose through the Maillard reaction, both lyophilized protein powders were incubated at $60^{\circ} \mathrm{C}$ and $35 \%$ relative humidity $(\mathrm{RH})$ for $0-6$ h. An incubator/humidity cabinet (L-200A; Tokyo Rikakikai Co., Ltd., Tokyo, Japan) was used for controlling the temperature and RH. In this study, myofibril alone (without sugar) was also lyophilized and incubated under the same conditions as the proteins-sugar mixtures containing glucose and maltose.

\section{Determination of available lysine and fructosamine}

Available lysine and fructosamine assays were carried out to evaluate the progress of the Maillard reaction between myofibrillar proteins and glucose or maltose. Myofibrillar proteins that reacted with glucose and maltose were dissolved in $20 \mathrm{mM}$ Tris- $\mathrm{HCl}$ buffer ( $\mathrm{pH} 7.5$ ) containing $0.5 \mathrm{M}$ $\mathrm{NaCl}$ with a high speed blender (Ultra-turrax T25-S1; IKALabotechnik, Staufen, Germany), precipitated with $7.5 \%$ trichloroacetic acid (TCA) (at final concentration) at room temperature for $30 \mathrm{~min}$. After removal of the Tris buffer, unreacted sugars, and TCA by decantation, the precipitated protein was redissolved in $50 \mathrm{mM}$ sodium phosphate buffer (pH 9.5) containing 2\% sodium dodecyl sulfate. Available lysine content was determined by spectrophotometric analysis using $O$-phthalaldehyde and $N$-acetyl-L-cysteine (Hernandez and Alvarez-Coque, 1992).

Myofibrillar proteins that reacted with glucose and maltose were dissolved in $20 \mathrm{mM}$ Tris- $\mathrm{HCl}$ buffer $(\mathrm{pH} 7.5)$ containing $0.5 \mathrm{M} \mathrm{NaCl}$ and dialyzed against the same buffer at $4^{\circ} \mathrm{C}$ for $16 \mathrm{~h}$ to remove unreacted sugars, and then fructosamine was assayed by the method of Johnson et al. (1983). Glycosylated human serum was used as a standard for determining fructosamine content which was regarded as the ketoamine content. The available lysine and fructosamine assays were performed within $48 \mathrm{~h}$ after sample preparation.

Solubility of glycosylated myofibrillar proteins Solubility of glycosylated myofibrillar proteins was measured according to a modified method of Saeki and Inoue (1997). After incubation for glycosylation, the protein powders were immediately mixed with $20 \mathrm{mM}$ Tris- $\mathrm{HCl}$ buffer $(\mathrm{pH} 7.5)$ containing 0.1 or $0.5 \mathrm{M} \mathrm{NaCl}$ at $1.5 \mathrm{mg} / \mathrm{mL}$ of the final protein concentration with the high speed blender at 10,000 rpm for $0.5 \mathrm{~min}$. After homogenization was repeated, the protein solution was centrifuged at $15,000 \mathrm{~g}$ for $30 \mathrm{~min}$ at $4^{\circ} \mathrm{C}$. Proteins in solution before and after centrifugation were precipitated with 7.5\% TCA (at final concentration) at room temperature for $30 \mathrm{~min}$. After removal of Tris buffer, unreacted sugars, and TCA by decantation, the precipitated protein was redissolved in $1 \mathrm{M} \mathrm{NaOH}$. The total solubility of the myofibrillar proteins was expressed as percent protein concentration in the supernatant with respect to that of the total protein solution before centrifugation.

Thermal stability Thermal stability was followed by monitoring changes in solubility of the protein solution dur- 
ing heating according to a modified method of Fujiwara et al. (1998). As Murphy et al. (1998) reported that thermal denaturation of chicken myofibrillar protein occurs at $53^{\circ} \mathrm{C}$, the incubation temperature was set at $50^{\circ} \mathrm{C}$ to examine the effect of the temperature of this denaturation area on solubility. Lyophilized myofibrillar proteins mixed with glucose and maltose at a weight ratio of $1: 6$ and 1:4, respectively, were kept at $60^{\circ} \mathrm{C}$ and $35 \% \mathrm{RH}$ for $6 \mathrm{~h}$. After incubation for glycosylation, the protein powders were immediately mixed with $40 \mathrm{mM}$ Tris-malate buffer (pH 7.5) containing 0.1 or 0.5 $\mathrm{M} \mathrm{NaCl}$ at $2 \mathrm{mg} / \mathrm{mL}$ of the final protein concentration with the high speed blender at $10,000 \mathrm{rpm}$ for $0.5 \mathrm{~min}$ twice (total of $1 \mathrm{~min}$ ) and dialyzed against the same $\mathrm{NaCl}$ solution at $4^{\circ} \mathrm{C}$ for $16 \mathrm{~h}$. Unreacted glucose and maltose were removed at this step. The dialyzate stood at $50^{\circ} \mathrm{C}$ for $2 \mathrm{~h}$ and then was centrifuged at $15,000 \mathrm{~g}$ for $30 \mathrm{~min}$ at $4^{\circ} \mathrm{C}$. Thermal stability was expressed as a percent of protein concentration in the supernatant with respect to that of the dialyzate before the 2-h incubation at $50^{\circ} \mathrm{C}$.

Protein determination Protein concentration was determined by the method of Lowry et al. (1951) using ovalbumin as the standard in the case of the available lysine assay, and the Biuret method (Gornall et al., 1949), using bovine serum albumin as the standard, was used for the other assays.

Statistical analyses All experiments were carried out with samples from at least three different lots of glycosylation. Values indicated in the figures are the means of at least 3 determinations, and the error bars indicate standard deviation. Student's $t$-test (Gosset, 1908) was used to determine the significance of differences among samples.

\section{Results and Discussion}

Reaction between myofibrillar proteins and glucose or maltose Figure 1 shows the change in available lysine and fructosamine contents in lyophilized myofibrillar proteins during reaction with glucose or maltose at $60^{\circ} \mathrm{C}$ and $35 \%$

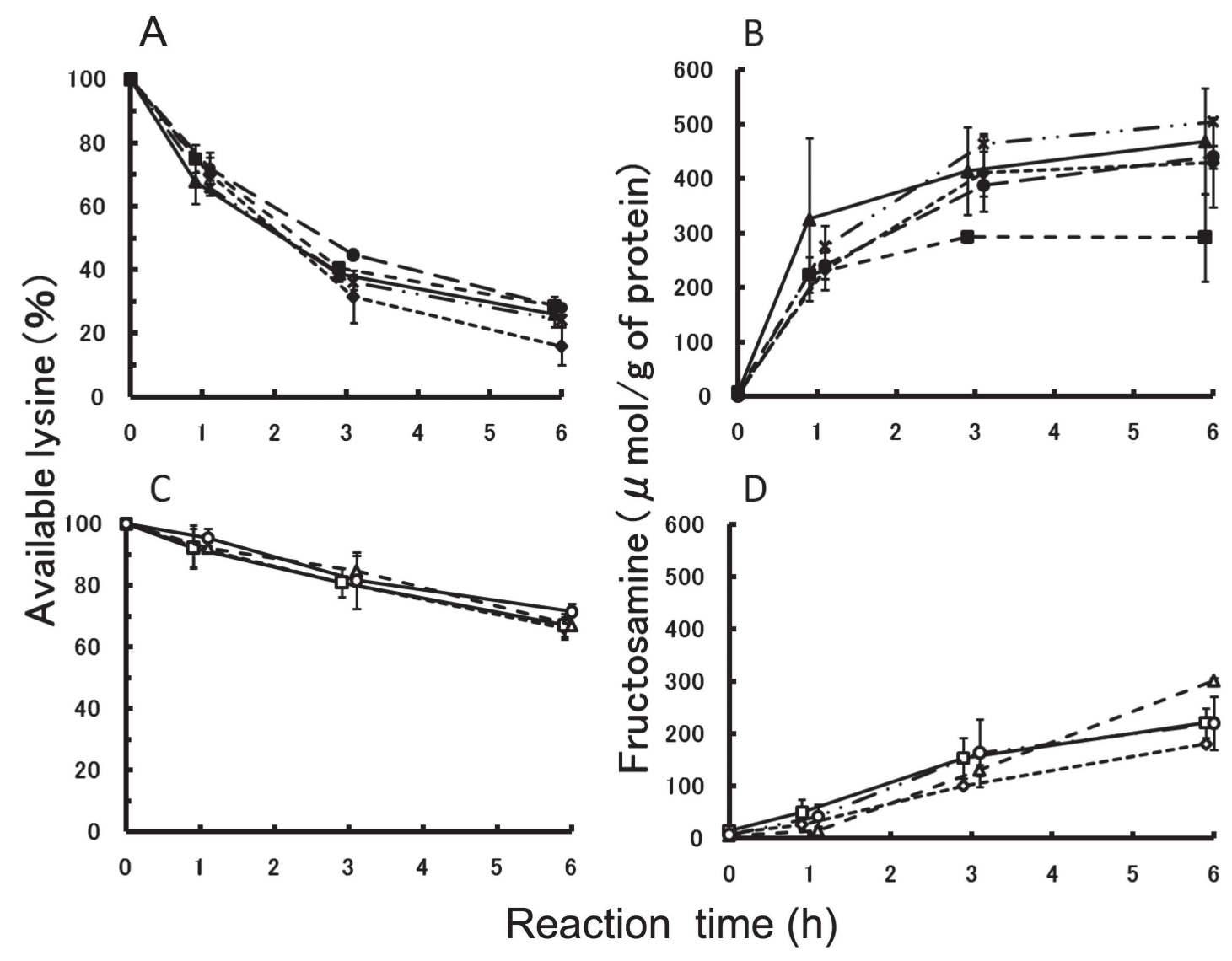

Fig. 1. Time-course changes in the concentrations of available lysine and fructosamine in myofibrillar proteins during the reaction with glucose and maltose at different mixing ratios of the myofibril and sugars.

Lyophilized myofibrillar protein-glucose mixture at weight ratios of 1:4 (-- $\mathbf{-}--), 1: 5\left(---_{-}\right), 1: 6(-\mathbf{\Delta}-), 1: 9(-\mathbf{0}-)$, and 1:18 ( $\cdots-\times-\cdots)$; lyophilized myofibrillar protein-maltose mixture at weight ratios of 1:3 (- $\diamond--), 1: 4(-\square-), 1: 5(-\triangle-)$, and 1:6 ( - $\bigcirc-\cdots)$ were held under $60^{\circ} \mathrm{C}$ and $35 \% \mathrm{RH}$ for $0,1,3$, and $6 \mathrm{~h}$, respectively. The amounts of available lysine in the glycosylated myofibrillar protein with glucose (A) and maltose (C) were recorded as the reaction progressed. Simultaneously, the quantities of fructosamine in the glycosylated myofibrillar protein with glucose (B) and maltose (D) were measured. 
RH. The amount of available lysine before incubation was $0.084 \pm 0.006 \mathrm{~g} / \mathrm{g}$ of protein $(\mathrm{n}=21)$. The available lysine content in protein glycosylated with glucose (Figure 1A) decreased with reaction time to the average of $24.6 \%$ after $6 \mathrm{~h}$, and the fructosamine content (Figure 1B) rose simultaneously to reach to the mean of $427.3 \mu \mathrm{mol} / \mathrm{g}$ of protein. Although some values showed significant differences with each other $(p<0.05)$, the progress of change in available lysine or fructosamine content was similar. When lyophilized myofibrillar proteins reacted with maltose, the available lysine content (Figure 1C) decreased to the average value of $68.0 \%$; there was no significant difference among all four proteins glycosylated with maltose. The fructosamine content (Figure 1D) rose to the mean of $230.9 \mu \mathrm{mol} / \mathrm{g}$ protein after the 6 -h incubation. Although some values showed significant differences from each other $(p<0.05)$, the progress of change in fructosamine content was similar. As for both proteins glycosylated with glucose and maltose, the molar quantity of fructosamine produced was almost equal to that of the available lysine reduced over $6 \mathrm{~h}$. When the lyophilized protein without sugar was incubated under the same conditions, the available lysine content remained unchanged and no fructosamine was produced. Additionally, patterns of SDS-polyacrylamide gel electrophoresis with 1\% 2-mercaptoethanol showed that myosin and actin mobility decreased with the reaction (data not shown). These results indicated that glucose or maltose react with the lysine residues in myofibrillar proteins. Glucose was then combined with a protein more promptly compared with maltose to generate fructosamine. This high reactivity is considered to be based on the molar quantity of the carbonyl group in glucose being twice as much as that in the same weight of maltose. This consideration was supported by the report that reactivity is extremely low in dextran - a polysaccharide (Fujiwara et al., 1998).

Proteins solubilized in low and high ionic strength media with glycosylation Changes of the solubility of proteins glycosylated with glucose and maltose in 0.1 and $0.5 \mathrm{M}$ $\mathrm{NaCl}$ are shown in Figures 2 and 3, respectively. The solubility of myofibrillar proteins in $0.5 \mathrm{M} \mathrm{NaCl}$ was about $80 \%$, which showed almost no change during $6 \mathrm{~h}$ of the Maillard reaction when glucose was used at mixing ratios of 1:18, 1:9 and 1:6, while it decreased during the glycosylation process to less than $60 \%$ when glucose was used at mixing ratios of 1:5 and 1:4 (Figure 2). Saeki and Inoue (1997) also observed

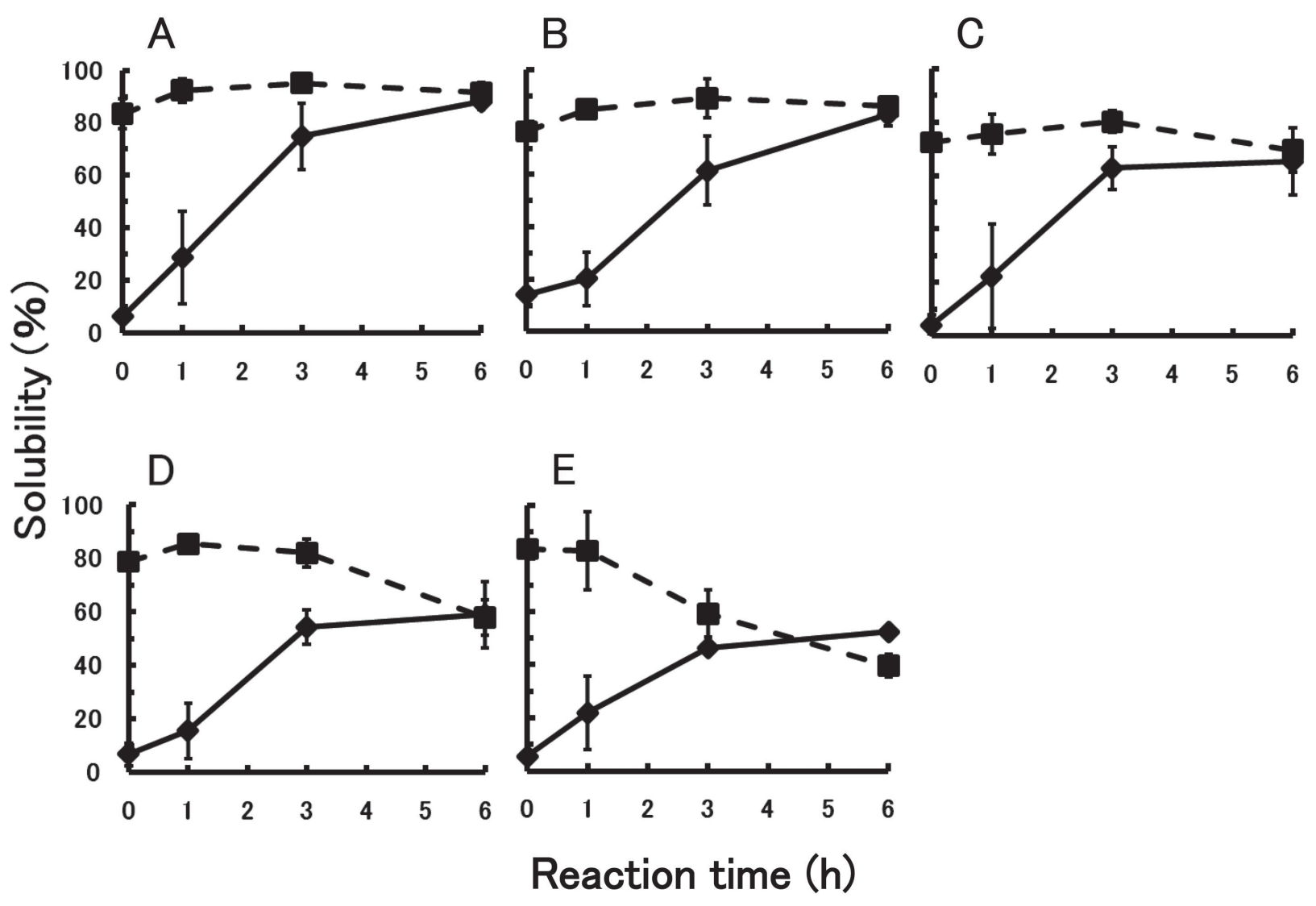

Fig. 2. Changes in the solubility of myofibrillar protein reacted with glucose. Lyophilized myofibrillar protein-glucose mixtures at weight ratios of 1:18 (A), 1:9 (B), 1:6 (C), 1:5 (D), and 1:4 (E) were held under $60^{\circ} \mathrm{C}$ and $35 \% \mathrm{RH}$ for $0,1,3$ and $6 \mathrm{~h}$, respectively; solubility of the myofibrillar protein in $0.1 \mathrm{M}(\bullet)$ and $0.5 \mathrm{M}(\boldsymbol{\square}) \mathrm{NaCl}$ solution (pH7.5) was measured. 
A

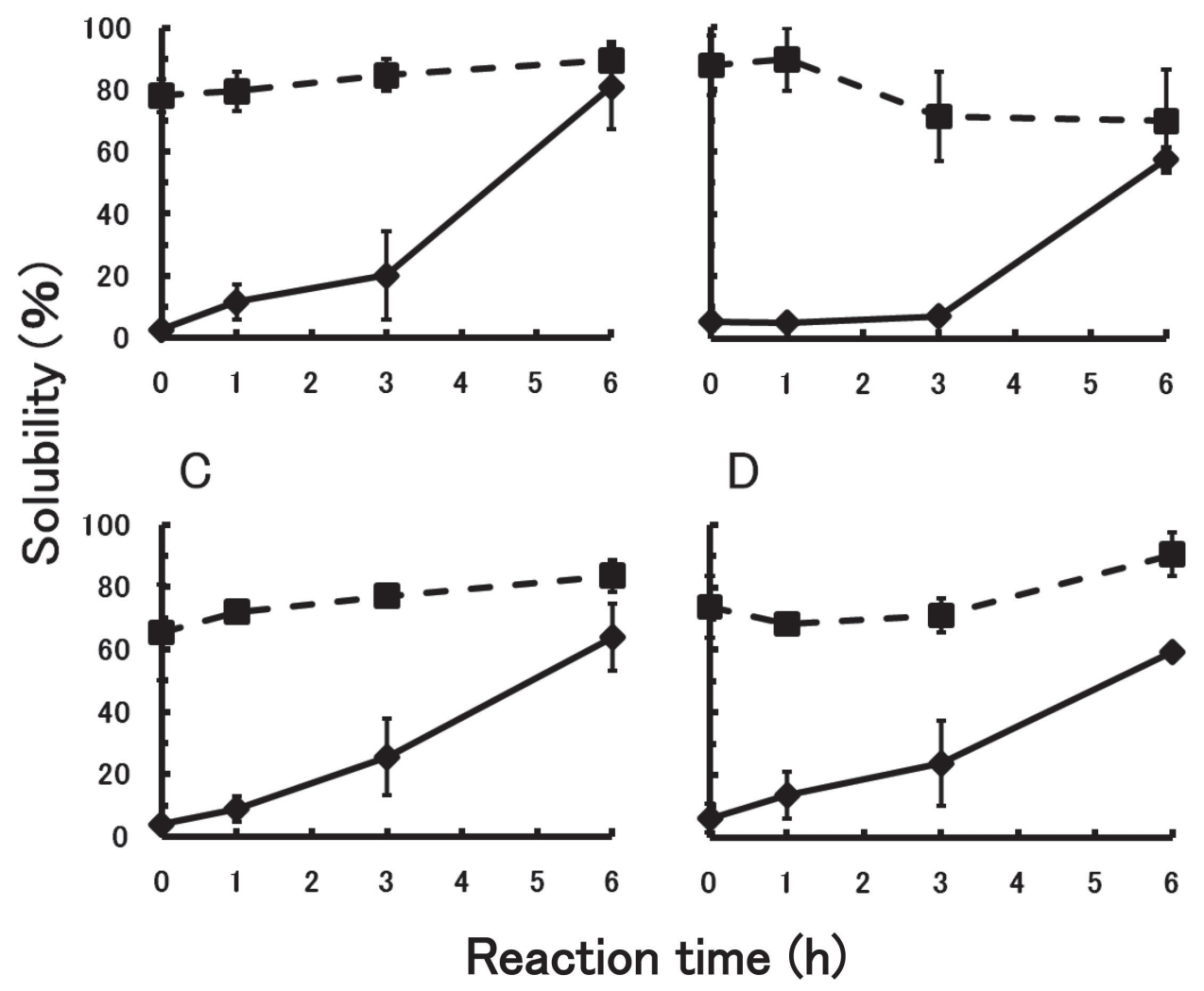

Fig. 3. Changes in the solubility of myofibrillar protein reacted with maltose. Lyophilized myofibrillar protein-maltose mixtures at weight ratios of 1:6 (A), 1:5 (B), 1:4 (C), and 1:3 (D) were held under $60^{\circ} \mathrm{C}$ and $35 \% \mathrm{RH}$ for $0,1,3$, and $6 \mathrm{~h}$, respectively; solubility of the myofibrillar protein in $0.1 \mathrm{M}(\diamond)$ and $0.5 \mathrm{M}(\boldsymbol{\square}) \mathrm{NaCl}$ solution $(\mathrm{pH} 7.5)$ was measured.

such decreases in solubility and suggested that the cause depended on heat denaturation of the myofibrillar proteins. Protein is known to be stabilized in the presence of glucose (Boye et al., 1996; Chen and Chang, 1998; Christ et al., 2005). As shown in Figures 1A and 1B, the progress of the Maillard reaction were similar among the myofibrillar protein-glucose systems, indicating that the loss of protein solubility with a decrease in glucose concentration in protein-glucose mixture (Figures 2D and 2E) seems to be caused by a shortage of glucose as a thermal protectant. On the other hand, the solubility in $0.1 \mathrm{M} \mathrm{NaCl}$ increased markedly with glycosylation, reaching $88.0 \pm 2.9,83.1 \pm 4.4,65.3 \pm 12.7,59.0 \pm 12.4$, and $52.4 \pm 1.4 \%(\mathrm{n}=3)$ after $6 \mathrm{~h}$ at mixing ratios of 1:18, 1:9, 1:6, $1: 5$, and 1:4, respectively. During glycosylation with glucose content 6 times that of the protein, protein denaturation in $0.5 \mathrm{M} \mathrm{NaCl}$ hardly occurred and the solubility of the protein in $0.1 \mathrm{M} \mathrm{NaCl}$ reached more than $60 \%$, suggesting that the minimum mixing ratio of myofibrillar protein to glucose was 1:6.

As for maltose (Figure 3), the solubility of myofibrillar proteins in $0.5 \mathrm{M} \mathrm{NaCl}$ was almost unchanged during $6 \mathrm{~h}$ of the Maillard reaction at the mixing ratios from 1:6 to 1:3 of myofibrillar protein to maltose. Izutsu et al. (2004) reported that maltose stabilizes the protein better than glucose. Thus, for maltose, a rapid decrease in solubility seen for glucose (Figures 2D and 2E) is not expected by this protective effect. The solubility in $0.1 \mathrm{M} \mathrm{NaCl}$ at the mixing ratio of $1: 6$ reached about $80 \%$, while other samples (at 1:3-5) attained about $60 \%$ after $6 \mathrm{~h}$.

Figures $1 \mathrm{~A}$ and 2 indicate that the solubility improvement of chicken myofibrillar proteins occurs when about $60 \%$ of available lysine reacts with glucose since the solubility improvement in low ionic strength medium occurred after 3 $\mathrm{h}$ of incubation. On the other hand, about $30 \%$ loss of available lysine is required to achieve solubility improvement with maltose, for which 6-h incubation was indispensable (Figures 1C and 3). As reported by Babij et al. (1991), about 200 lysine residues exist in a molecule of myosin heavy chain, and about 120 glucose and 60 maltose molecules were considered to be conjugated with a myosin heavy chain 
when the solubility improvement occurred. One molecule of glucose has 5 hydroxy groups, while 8 hydroxy groups exist in maltose, including a hydroxyl group connected with an anomeric carbon. Thus, the total number of hydroxy groups in these sugar molecules is 600 and 480, respectively. However, the number of hydroxy groups connected by the anomeric carbon for combining with lysine was increased by ring-opening, resulting in invariability of the total number of hydroxy groups. Although there is a small difference between the numbers of hydroxy groups per a myosin heavy chain, we assumed that about 500 hydroxy groups are conjugated with one myosin heavy chain to increase the hydration with water allowing for solubility of myofibrillar protein. Katayama et al. (2002) suggested the dissociation of myosin and actin due to a structural impediment on the actin-binding site in subfragment 1 by the attached glucose as one cause of solubility improvement. Moreover, the $\varepsilon$-amino group of lysine residues has been shown to play an important role in the self -association of the myosin rod filaments (McLachlan and Karn, 1982; Kato and Konno, 2000). Katayama and Saeki (2007) also suggested that water solubilization is caused by the loss of the filament-forming ability by glycosylation. Of course, such a steric hindrance must also take part in solubility improvement.
Thermal stability Unglycosylated myofibrillar protein and those glycosylated with 6 times of glucose and 4 times of maltose were dissolved in 0.1 and $0.5 \mathrm{M} \mathrm{NaCl}$ solutions $(\mathrm{pH}$ 7.5) and then heated at $50^{\circ} \mathrm{C}$ for $2 \mathrm{~h}$. Although there were not conspicuous differences between the solubility of myofibrillar proteins glycosylated with 3-5 times of maltose in $0.1 \mathrm{M}$ $\mathrm{NaCl}$ (Figure 3), the solubility in $0.1 \mathrm{M} \mathrm{NaCl}$ was the highest at the mixing ratio of 1:4 for myofibrillar protein to maltose when the reaction time was extended by $24 \mathrm{~h}$ (Nishimura et al. in press). Accordingly, the mixing ratio of 1:4 was chosen to examine thermal stability. Figure 4 shows the solubility of glycosylated and unglycosylated myofibrillar protein before and after heating. Unglycosylated myofibrillar protein in 0.5 $\mathrm{M} \mathrm{NaCl}$ decreased significantly from $66 \%$ to $13 \%(p<0.01)$ during heat treatment. However, for myofibrillar protein containing glucose and maltose in $0.1 \mathrm{M}$ and $0.5 \mathrm{M} \mathrm{NaCl}$, a significant decrease in solubility was not observed at the start or end of the 2-h heating. These results indicate that the thermal stability of chicken myofibrillar protein is improved by conjugation with both sugars and that the mixing ratios of 1:6 and 1:4 for myofibrillar proteins to glucose and maltose, respectively, is enough to acquire thermal stability in 0.1 and $0.5 \mathrm{M} \mathrm{NaCl}$. This improvement in the thermal stability of myofibrillar protein might be caused by suppressing thermal

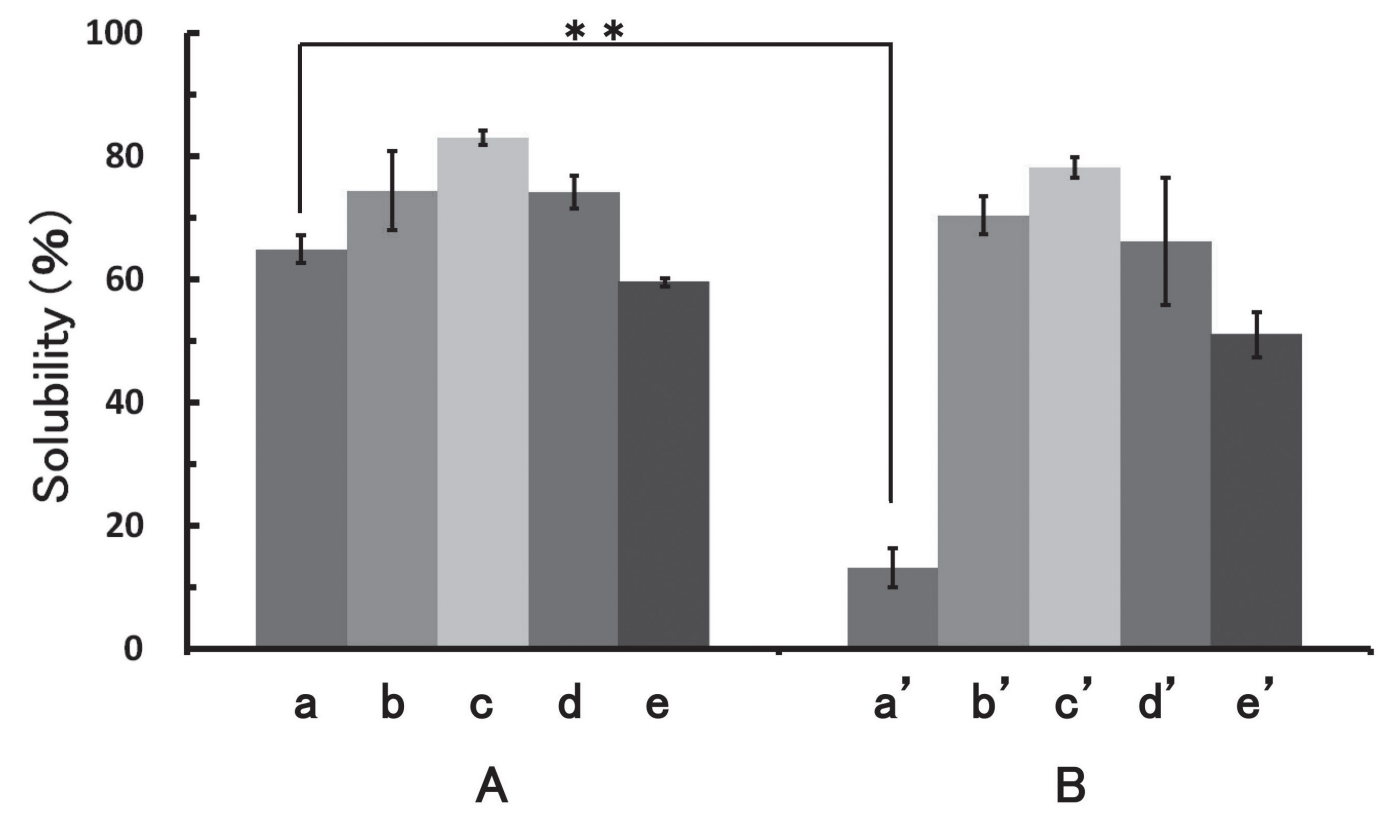

Fig. 4. Effects of glycosylation with glucose or maltose on the thermal stability of myofibrillar protein.

Group A shows the solubility of each type of glycosylated myofibrillar protein before 2-h incubation at $50^{\circ} \mathrm{C}$. Group B shows the solubility of each type of glycosylated myofibrillar protein after incubation. Myofibrillar protein in $0.5 \mathrm{M} \mathrm{NaCl}$ solution (a and a'), myofibrillar protein glycosylated with $6 \times$ glucose (b and b'), and myofibrillar protein glycosylated with $4 \times$ maltose (c and c') in $0.5 \mathrm{M} \mathrm{NaCl}$ solution. The same neoglycoproteins including glucose ( $\mathrm{d}$ and d') and maltose (e and e') in $0.1 \mathrm{M}$ $\mathrm{NaCl}$ solution. They were incubated for $2 \mathrm{~h}$ at $50^{\circ} \mathrm{C}$, and the solubility before and after 2-h incubation at $50^{\circ} \mathrm{C}$ for each type of sample was calculated. $* * p<0.01$. 
aggregation of myosin by attaching sugars and the increase of hydration with water due to the presence of a sufficient amount of hydroxy groups.

Chicken myofibrillar protein glycosylated with glucose and maltose at mixing ratios of $1: 6$ and 1:4, respectively, through 6-h incubation at $60^{\circ} \mathrm{C}$ and $35 \% \mathrm{RH}$ improved both the solubility and thermal stability. In particular, the functional change in chicken myofibrillar protein did not require the large amount of glucose which carp myofibrillar protein demanded. Takeda et al. (2007) already examined the feasibility of industrial application and indicated the strong potential of protein glycosylation for use with spawned-out chum salmon. These results indicate that glycosylated chicken myofibril could be an available new food material.

Acknowledgment This study was partially carried out by supporting program (2008) of the SKYLARK Food Science Institute.

\section{References}

Babij, P., Kelly, C. and Perisamy, M. (1991). Characterization of a mammalian smooth muscle myosin heavy chain gene: complete nucleotide and protein coding sequence and analysis of the 5' end of the gene. Proc. Natl. Acad. Sci. USA, 88, 10676-10680.

Boye, J.I., Alli, I. and Ismail, A.A. (1996). Interactions involved in the gelation of bovine serum albumin. J. Agric. Food Chem., 44, 996-1004.

Chen, C.C. and Hung-Min Chang, H.M. (1998). Effect of thermal protectants on the stability of bovine milk immunoglobulin G. $J$. Agric. Food Chem., 46, 3570-3576.

Christ, D., Takeuchi, K.P. and Cunha, R.L. (2005). Effect of sucrose addition and heat treatment on egg albumen protein gelation. $J$. Food Sci., 70, E230-E238.

Connell, J.J. (1961). The relative stabilities of the skeletal-muscle myosins of some animals. Biochem. J., 80, 503-509.

Fujiwara, K., Oosawa, T. and Saeki, H. (1998). Improved thermal stability and emulsifying properties of carp myofibrillar proteins by conjugation with dextran. J. Agric. Food Chem., 46, 12571261.

Gornall, A.G., Bardwill, C.J. and David, M.M. (1949). Determination of serum proteins by means of the biuret reaction. J. Biol. Chem., 177, 751-766.

Gosset, W.S. (1908). The probable error of a mean. Biometrika, 6, $1-24$.

Hernandez, M.J.M. and Alvarez-Coque, M.C.G. (1992). Available lysine in protein, assay using $o$-phthalaldehyde $/ N$-acetyl-Lcysteine spectrophotometric method. J. Food Sci., 57, 503-505.
Izutsu, K., Aoyagi, N. and Kojima, S. (2004). Protection of protein secondary structure by saccharides of different molecular weights during freeze-drying. Chem. Pharm. Bull., 52, 199-203.

Johnson, R.N., Metcalf, P.A. and Baker, J.R. (1983). Fructosamine: a new approach to the estimation of serum glycosylprotein. An index of diabetic control. Clin. Chim. Acta, 127, 87-95.

Katayama, S., Shima, J. and Saeki, H. (2002). Solubility improvement of shellfish muscle proteins by reaction with glucose and its soluble state in low-ionic strength medium. J. Agric. Food Chem., 50, 4327-4332.

Katayama, S. and Saeki, H. (2007). Water solubilization of glycated carp and scallop myosin rod, and their soluble state under physiological conditions. Fish. Sci., 73, 446-452.

Kato, S. and Konno, K. (2000). Filament formation of carboxyland amino-group-modified carp myosin rod. Fish. Sci., 66, 124129.

Lowry, O.H., Rosebrough, N.J., Farr, A.L. and Randall, R.J. (1951). Protein measurement with the Folin phenol reagent. J. Biol. Chem., 193, 265-275.

McLachlan, A.D. and Karn, J. (1982). Periodic charge distributions in the myosin rod amino acid sequence match cross-bridge spacings in muscle. Nature, 299, 226-231.

Murphy, R.Y., Marks, B.P. and Marcy, J.A. (1998). Apparent specific heat of chicken breast patties and their constituent proteins by differential scanning calorimetry. J. Food Sci., 63, 88-91.

Nishimura, K. Murakoshi, M. Katayama, S. and Saeki, H. Antioxidative ability of chicken myofibrillar protein developed by glycosylation and changes in solubility and thermal stability. Biosci, Biotech, Biochem., In press.

Saeki, H. (1997). Preparation of neoglycoprotein from carp myofibrillar protein by Maillard reaction with glucose: Biochemical properties and emulsifying properties. J. Agric. Food Chem., 45, 680-684.

Saeki, H. and Inoue, K. (1997). Improved solubility of carp myofibrillar proteins in low ionic strength medium by glycosylation. $J$. Agric. Food Chem., 45, 3419-3422.

Saeki, H. and Tanabe, M. (1999). Change in solubility of carp myofibrillar protein by glycosylation with ribose. Fish. Sci., 65, 967968.

Takeda, H., Iida, T., Okada, A., Ootsuka, H., Ohshita, T., Matsutani, E., Katayama, S. and Saeki, H. (2007). Feasibility study on water solubilization of spawned out salmon meat by conjugation with alginate oligosaccharide. Fish. Sci., 73, 924-930.

Youling, L.X. (2000). Food Proteins. In "Meat Processing” ed. by S. Nakai and H.W. Modler. Wiley-VCH, Inc., NY, pp. 89-145. 